\title{
Iran's Islamic Revolutionary Guards Corps (IRGC): More Than A Branch Of Armed Forces
}

\author{
Hamza Demirel
}

\begin{abstract}
This study aims at analyzing the role of the Islamic Revolutionary Guards Corps' (IRGC) extraterritorial activities in attaining Iran's foreign policy goals. The regime has deliberately supported several armed non-state actors to achieve the goals, particularly as seen in its relations with Lebanese Hezbollah and Shia groups in Iraq, the IRGC has served as a node in providing a broad range of state support. Although the IRGC has the characteristics of conventional armed forces, its extraterritorial activities contradict the legal frame of 'use of military force' and mostly fit the characteristics of 'state sponsorship of terrorism.' Moreover, these activities challenge international norms and provoke other regional actors. This condition creates an obstacle to Iran's integration into the international system which is increasingly globalized and interconnected and an environment which is costly to live within and leaves it isolated. These attitudes paradoxically place Iran in a situation that challenges the goals of 'state security and survival' and 'becoming the regional power' in the long run. Thus, it is argued that the real reason behind the regime's insistence on this strategy is preserving the current political system and the power of current ruling elites; in brief, it is labeled 'regime survival' in this study.
\end{abstract}

The 1979 Iranian Revolution is the most important turning point in Iran's recent history. The revolution put Iran in a controversial and exceptional position in the Islamic World, and the regional and global arena. There were many factors that constituted ground for the revolution. Particularly, the Shiite clerical power in society can be accepted as the most important one.

Since 1501, when Shiism became the state religion with compulsory conversion as a political move against the expansion of foreign influences, Shiism and clerics have been an active component of Iranian politics. In a series of events, the Tobacco Monopoly revolt (18901891), the Constitutional Revolution (1905-1906), the Oil Nationalization Movement of Prime Minister Mohammad Mosaddegh (1951-1953), and the Iranian Islamic Revolution (1978-1979), reactions to the domination of Iran and exploitation of its wealth and resources by foreign powers, clergies played a prominent role. Their historically rooted influence and well-established network in society made them a victor of the 1979 Revolution under Khomeini's leadership.

The 1979 Iranian Revolution was not merely a change in rulers. It made Khomeini's ideology, which is a blend of his interpretation of Shiism and Persian nationalism, the dominant characteristic of the post-revolutionary era, and has influenced every aspect of life. The revolution has changed its political structure, the priorities of policy makers, the economic spheres of Iran, but even more fundamentally, culture and society. After the revolution, Iran declared itself a theocratic republic guided by religious principles and named itself the Islamic Republic of Iran. The revolution also completely transformed Iran's foreign policy and 
international standing.

Throughout Iranian revolutionary foreign policy history, the pattern of Iran's external behavior were directly or indirectly determined by numerous factors: Iran's geographical and demographic realities, historical experience (lessons learned), post-revolutionary ideology which is a blend of nationalism and Khomeini's interpretation of Shiism, the post-revolutionary political structure and decision-making process, national interests, immediate domestic needs, ruling elites' priorities (ideological/individual), regional improvements and threat perceptions.

Based on observations and assessments from internal and external determinants of Iran's foreign policy making, Iran's foreign policy goals are defined as follows: Regime survival is the indispensable (sine qua non) goal of Iranian foreign policy and above all else; State security and survival (the defense of Iranian territory against external threats); Projecting power and becoming the dominant power in the region. The goal of 'regime survival' is an outcome of Khomeini's ideology as well as his heritage, and occupies first place in the Iranian leader's agenda and directly affects domestic and foreign affairs decision-making.

Iran employs a number of different tools in attaining these foreign policy goals. Among them, the IRGC is the most crucial and controversial one. The IRGC has actively taken the lead in achieving all three goals, the preservation of the regime is a unique task and its reason for existence. However, the IRGC's way of achieving these goals are very controversial.

Iran deliberately supported several armed non-state actors and provided them a broad range of state support in the form of ideological direction, organizational assistance, diplomatic backing, training, operational direction, money, arms, logistics, and sanctuary. The IRGC has served as an outpost o provide this support.

The regime's initial ideological motivations, parallel to changes in foreign policy approaches, have been replaced with rational and strategic calculations. The need for foreign capital and technical expertise to carry out economic reconstruction, which mostly originated from the costly Iran-Iraq war and international isolation, made this transformation a necessity. However, the IRGC's extraterritorial-capability has always been used it covertly and professionally. In terms of strategic purposes, the IRGC's extraterritorial activities served as a tool of deterrence and retaliatory force against the adversaries of Iran, a bargaining chip and a way of projecting power to different audiences.

The controversial nature of these activities emerges at this point. Despite the fact that the IRGC has the characteristics of a regular conventional armed force, based on the international law and state sponsorship of terrorism literature, the IRGC's extraterritorial activities are outside the legal frame of 'use of military force' and mostly fit the characteristics of 'state sponsorship of terrorism.' 
If we take into account Iran's foreign policy goals which are very common for all states, the IRGC's extraterritorial activities as a strategy to achieve these goals challenge international norms and provoke other regional actors who are mostly Sunni and have strong prejudices against Iran. This condition creates an obstacle to Iran's integration into the international system, which is increasingly globalized and interconnected, and an environment, which is costly for Iran to live within and highly isolating. Paradoxically, these attitudes put Iran in a situation that contradicts the goals of 'state security and survival' and 'becoming the regional power.'

Thus, the real reason behind the regime's insistence for this strategy is preserving the current political system and the power of current ruling elites. Briefly, it is called 'regime survival' in this study. There are several issues that have created this phenomenon. In the following section, the reasons that have created the ruling elites' motivations and sensitivity of regime survival will be addressed.

\section{Structural and Ideological Basis of Regime Survival}

As stated by Hunter, "the character of states' political systems and their decision-making apparatus and processes greatly influence their external behavior." 1 The 1979 Iranian revolution was not merely a ruler change. In Walt's words, it created the new principles of legitimacy, new symbols of authority and identity, new rules for elite recruitment, new political institutions, and governmental procedures. ${ }^{2}$ Walt's definition of 'a sharp departure from those of the old regime'3 explains what happened in Iran with the 1979 Revolution. Following the revolution, Khomeini's ideological doctrines formed all facets of life: political, educational, legal, social, and religious.

The main concern of the new political leadership was the survival of the newly established political regime. Survival was the raison d'etre of the new polity. Khomeini defined regime preservation as the highest priority even over fundamental religious practices. In the words of Stanley, Khomeini's formulation regarding the survival of the regime is as follows; “the regime is the embodiment of Shia Islam's authority on Earth and to abandon it would be to abandon the will of God. Thus, the survival of this government and its form is an existential imperative as well as an expression of self-interest and Iranian nationalism."

The political system of the Islamic Republic, which enjoys the concept of velayat-e faqih and republican characteristics, is the embodied form of Khomeini's ideology. The preservation of the Islamic Republic is defined as the ultimate religious value of the regime's ideology by Khomeini which can be died for. Tucker quotes Stephen Hanson's “ideology unites activists around a set of shared beliefs and symbols and provides a 'higher cause' that legitimates their

\footnotetext{
${ }^{1}$ Hunter, Iran's Foreign Policy in the Post-Soviet Era, 20.

2 Walt, "Revolution and War," 1992, 334.

${ }^{3}$ Walt, "Revolution and War," 1992, 140.

${ }^{4}$ Stanley, "The Strategic Culture of the Islamic Republic of Iran," 4.
} 
struggle." Regime preservation (hefz-e nezam) has been a 'higher cause' of revolutionary ideology. The IRGC, which can be characterized as the loyal armed forces of the regime, by definition 'guardian of the revolution,' has been the primary instrument for implementing this task.

Moreover, the political structure, institutions, rules for elite recruitment, and governmental procedures have been designed accordingly. The Supreme leader, and several institutions -particularly unelected components of the regime- have been loyal protectors of the regime. The ultimate power of the Supreme Leader and unelected institutions' (such as partly unelected Guardian Council and Expediency Council) influence on decision-making establishes an elaborate system of checks and balances, which seek to ensure regime survival and to maintain the status quo. To prevent potential instability that was a threat to the regime, Khomeini established the Expediency Council in 1988 to mediate disputes between the Parliament and the Guardian Council. Even this decision was made in order to preserve the regime in case of political dispute that might harm the regime's legitimacy. The IRGC, which is an institutional armed organization and an alternative to the regular army, is established solely to preserve the regime. Thus, the political structure is designed in a way to prevent any individual, institution, and faction from dominating the system and several institutions are created to insulate the regime against internal and external threats.

With these characteristics it is not easy to position Iran in a particular regime type. As stated by Chebabi, Iran "[1]ike totalitarian regimes, it proclaims the absolute supremacy over public life of an ideology, i.e. 'Islam'; like authoritarian regimes it permits a limited degree of pluralism; and like democracies it holds elections in which the people sometimes have a genuine choice, to wit Mohammad Khatami's upset victory in the presidential elections of May $1997 \ldots . . . " 6$ The regime has totalitarian, authoritarian, and democratic features. Furthermore, after the Ahmadinejad presidency, the IRGC's increasing influence on strategic decision-making and cultural life started the debate of Iran's being a 'praetorian state. ${ }^{77}$ For the sake of simplification, as classified by Rakel, the regime type can be defined as close to totalitarian during Khomeini's leadership; since 1989 as authoritarian with some limited democratic features. ${ }^{8}$

Khomeini named the new regime as 'Islamic republic.' He avoided to use the very notion of democracy that is an undesirable Western concept and stated that 'Islam itself is democratic.' Although the new regime was born of a popular movement that inherently had democratic aspirations; in practice, since establishment, the ruling elite has violated them in many ways that range from the manipulation of electoral processes, inhibiting free speech, human rights

\footnotetext{
5 Joshua Tucker, "Some Thoughts on Authoritarian Durability in the Middle East," The Monkey Cage, February 21, 2011, http://themonkeycage.org/2011/02/some_thoughts_on_authoritarian/.

${ }^{6}$ Chehabi, "The Political Regime of the Islamic Republic of Iran in Comparative Perspective," 48.

${ }^{7}$ Hen-Tov and Gonzalez, "The Militarization of Post-Khomeini Iran," 45.

${ }^{8}$ Rakel, Power, Islam, and Political Elite in Iran, 2009, 18:27.
} 
violations, and suppression of all opposition to control of the media. The regime did not refrain from acting in undemocratic ways. ${ }^{9}$ The regime's priority has been survival, and its leaders' priority has been to stay in power, not democratic republican aspirations.

Skuldt, in her study, draws attentions to the connection between the regime survival strategies and Buena de Mesquita et al.'s selectorate theory. ${ }^{10}$ I also find this approach useful in explaining the dynamics between regime survival and the IRGC's extraterritorial activities. As stated by the authors of The Logic of Political Survival, all political leaders' -whether democratic or autocratic, in any type of regime- primary objective is to remain in power. In their words,

Our starting point is that every political leader faces the challenge of how to hold on to his or her job. The politics behind survival in office is, we believe, the essence of politics. The desire to survive motivates the selection of policies and the allocation of benefits; it shapes the selection of political institutions and the objectives of foreign policy; it influences the very evolution of political life. We take as axiomatic that everyone in a position of authority wants to keep that authority and that it is the maneuvering to do so that is central to politics in any type of regime. ${ }^{11}$

According to the authors, in order to survive, the leaders need to create and maintain a winning coalition in exchange for a share of public/private goods. The winning coalition, which is the faction that keeps a leader in power, emerges from a group called the selectorate that is authorized to choose the leader. The leadership position is always desirable and therefore competitive. Thus, all leaders are preoccupied with their survival against a challenger.

In order to remain in power, the leader must guarantee the winning coalition's support by allocating resources to the members of the coalition. In a democracy, the size of the winning coalition is larger relative to the size of the selectorate than in autocracies. The leaders try to generate more support by providing public goods to the coalition's members. This ends up in a probability that a member of the winning coalition may join a challenger's coalition with the belief of continuing to receive the same benefits. In an autocracy, the winning coalition is smaller and each member has more to gain or lose, because given valuable private goods are not accessible to the larger population instead of equably distributed public goods. In the words of the authors; "the survival of leaders in small winning coalition systems depends on their ability to provide private goods to their supporters." gains, in turn, generate stronger loyalty. The members of small winning coalitions have much to lose if the leader is replaced, and thus as long as the leader remains in power, it means that they

\footnotetext{
${ }^{9}$ Alex Vatanka, “The Authoritarian Resurgence: Iran Abroad," Middle East Institute, April 30, 2015, http://www.mei.edu/content/article/authoritarian-resurgence-iran-abroad.

${ }^{10}$ Skuldt, "State Sponsored Terrorism?"

${ }^{11}$ Bruce Bueno de Mesquita et al., The Logic of Political Survival (Cambridge, MA; London: MIT Press, 2003), 89.

${ }^{12}$ Ibid., 102.
} 
guarantee the expected benefits.

Given this context, in the case of Iran there are two levels of winning coalitions that originate from the nature of the dual political system; the first includes unelected components of the political structure -such as the members of the Expediency Council, Guardian Council, Head of Judiciary, Commanders of the Armed Forces- under the leadership of the supreme leader, mostly conservatives that have a long history in this coalition; the second gathers around the president who constitutes the elected component of the political structure.

The leaders and members of the IRGC have been part of the permanent winning coalition since the revolution. Their power and wealth have grown over time. As one of the beneficiaries of the regime, the IRGC has always been loyal to the supreme leader and the regime and always played a key role against both internal and external threats. Because, as mentioned earlier, it is clear that the IRGC's institutional survival is dependent on the regime's survival. Mutual dependency between the IRGC and the regime and the IRGC's benefits from the regime makes sense in terms of the logic of 'winning coalition'.

\section{Domestic and External Threats against the Regime}

During the first decade of the revolution, the regime was dominated by Khomeini as the leader and moral authority of the revolution. The consolidation of the new regime had been the primary goal during his leadership. Instead of a power struggle among Khomeinists, the regime faced threats from 'others' who did not have any connection to Khomeini. The initial domestic threats originated from ethnic fragmentation and military coup attempts. The IRGC was Khomeini's 'strongest weapon' in suppressing the opposition and uprisings of separatist minorities. Keddie characterizes the Khomeini period as follows: “The decade of Khomeini's rule was marked by the ever-growing power of his followers and elimination, often by violence and despite resistance, of opposition groups, and by increasing enforcement of ideological and behavioral controls on the population."13 Besides these domestic factors, in particularly the IRGC's role in the Iran-Iraq war and the task of 'exporting the revolution' contribute to further consolidation and institutionalization of the revolution.

In the post-Khomeini period, increasing factionalism -particularly Khatami's reformist domestic and foreign policies were perceived as a threat that might erode the ideological precepts of the revolution and conservatives power. Then, the conservatives adopted a strategy that expanded their dominance in the power structure.

Additionally, the US invasion of Iraq and Afghanistan in 2003 led to the enlarged presence of the United States and paved the way for its settling in the region. Although Iran's sworn enemies, the Saddam regime and Taliban, no longer being a threat, Iran was surrounded by US military supremacy. Furthermore, the US and Israel's explicit threats and talk of regime

\footnotetext{
${ }^{13}$ Keddie, Modern Iran: Roots and Results of Revolution, 241.
} 
change caused unease among Iranian ruling elites. Thus, the regime adopted a multifaceted strategy, which ranged from improving nuclear weapons and ballistic missiles to the use of proxy groups. Since 1997, and particularly after September 11, 2001, the IRGC has taken the vital role of challenging both internal and external vulnerabilities. This has resulted in increasing the power of the IRGC and subsequently the militarization of the political system to some extent.

The IRGC has been an active part of regime survival strategies as a loyal supporter with its Basij force, which is the principle force responsible for upholding Islamic norms in society and social control at home; and with the Quds Force, which is an intelligence and unconventional warfare component of the IRGC abroad.

\section{Need for Legitimacy}

In any type of regime, democratic or autocratic, the maintenance of power and stability of the political system necessitate the pursuit of legitimacy -"the terms by which people recognize, defend, and accept political authority" ${ }^{314}$ According to Weber, an authority becomes valid once the actors subject to it believe in its legitimacy. In his words:

Custom, personal advantage, purely affectual or ideal motives of solidarity do not form a sufficiently reliable basis for a given domination. In addition there is normally a further element, the belief in legitimacy. ${ }^{15}$

As stated by Campell, "Weber holds that beliefs in legitimacy maintain the stability of an order of domination he by no means wishes to confer any actual legitimacy upon that order."16 According to him, Weber emphasizes here the empirical significance of validity. In the words of Weber:

Experience shows that in no instance does domination voluntarily limit itself to the appeal to material or affectual or ideal motives as the basis for its continuance. In addition every such system attempts to establish and to cultivate the belief in its legitimacy. ${ }^{17}$

Lipset defined legitimacy as the "capacity of the system to engender and maintain the belief that the existing political institutions are the most appropriate one for the society"18

Both Weber and Lipset emphasized the ability of a ruler to persuade the ruled of the

\footnotetext{
${ }^{14}$ Mlada Bukovansky, Legitimacy and Power Politics: The American and French Revolutions in International Political Culture, Princeton Studies in International History and Politics (Princeton, NJ: Princeton University Press, 2002), 2.

${ }^{15}$ Max Weber, Economy and Society: An Outline of Interpretive Sociology (Berkeley: University of California Press, 1978), 213.

${ }^{16}$ David Campbell, "Truth Claims and Value-Freedom in the Treatment of Legitimacy: The Case of Weber," Journal of Law and Society 13, no. 2 (1986): 209, doi:10.2307/1410281.

${ }^{17}$ Weber, Economy and Society, 213.

${ }^{18}$ Seymour Martin Lipset, Political Man; the Social Bases of Politics, First Edition, Doubleday Anchor Books (Garden City, NY: Anchor Books, 1963), 64.
} 
legitimate nature of a political system. In a broader sense, the system is legitimate insofar as people believe that it should be obeyed. Thus, legitimacy can be accepted as a powerful ordering tool and "a necessary component of authority and thus of power."19

As Weber pointed out, the modes of legitimation may include tradition, charisma or rational-legal authority: Tradition, "the authority of the "eternal yesterday", i.e. of the mores sanctified through the unimaginably ancient recognition and habitual orientation to conform"; Charisma "the authority of the extraordinary and personal gift of grace (charisma), the absolutely personal devotion and personal confidence in revelation, heroism, or other qualities of individual leadership"; Rational-legal authority "domination by virtue of "legality", by virtue of the belief in the validity of legal statute and functional "competence" based on rationally created rules." 20 For instance, contemporary nation-states in the Western world can be classified as Rational-legal authorities; some states may blend various type of legitimations.

As stated by White, "all regimes, from naked tyrannies to pluralistic democracies, seek to legitimate themselves." ${ }^{21}$ Although the pursuit of legitimacy is a necessity for all kind of regimes, it proves significantly more difficult for the authoritarian states. For authoritarian regimes there are essentially two ways to keep domestic stability and maintain power: coercion and repression on one side, the quest for legitimacy on the other. In Non-Democratic Regimes: Theory, Government and Politics, for a new dictatorship, Brooker put forward the same prescription in different words. His two-pronged approach is as follows:

- The new regime claims to be legitimate and seeks to have its claims to legitimacy accepted by state and society.

- It also deploys a range of organizations, organs or administrative devices that strengthen its (at least partially coercive) control over state and society -so that even if the claims to legitimacy are unsuccessful, the regime may still be able to hold and effectively use the public offices/powers it has seized or misappropriated. ${ }^{22}$

Although Brooker proposes these means for a new dictatorship, I believe that these are valid for most of the non-democratic regimes.

Brooker's first approach includes two ways of seeking legitimacy: electoral means of legitimation and ideological means of legitimation. In electoral means of legitimation, the regime uses "an electoral/democratic façade is in a sense their recognition that public offices should

\footnotetext{
${ }^{19}$ Bukovansky, Legitimacy and Power Politics, 70.

${ }^{20}$ Max Weber, From Max Weber: Essays in Sociology, Routledge Sociology Classics (Milton Park, Abingdon, Oxon ; New York: Routledge, 2009), 78-79.

${ }^{21}$ Stephen White, "Economic Performance and Communist Legitimacy," World Politics 38, no. 3 (1986): 462, doi: $10.2307 / 2010202$.

${ }^{22}$ Paul Brooker, Non-Democratic Regimes: Theory, Government and Politics (New York, NY: St Martin's Press, 2000), 101.
} 
indeed he owned by the public and that to be legitimate a government must be based upon the people's choice, the popular will, or some other democratic basis."23 Although ideological legitimation has not been as common as the electoral legitimation, it can be observed in several cases. In ideological legitimation, the ruler or the regime has the right to rule based on ideological values. According to Brooker it is "to some extent the modern equivalent of the now largely extinct religious claims to legitimacy."24

North analyzes ideology's effect in seeking legitimacy. Regimes need to depend on some ideational element or ideology to legitimize their rule by establishing an abstract relation between the ruler and the ruled. He links legitimacy to policing cost. Legitimacy created by ideology is a cost-effective method of ruling. In the words of North:

The costs of maintenance of an existing order arc inversely related to the perceived legitimacy of the existing system. To the extent that the participants believe the system fair, the costs of enforcing the rules and property rights are enormously reduced by the simple fact that the individuals will not disobey the rules or violate property rights even when a private cost/benefit calculus would make such action worthwhile. $^{25}$

Brooker's second approach for maintaining power and preserving stability is strengthening control, which can be defined as coercion and repression. As an important source of stability, and to strengthen their control over state and society, the regimes "deploy a (competent) security/intelligence organ or organization." 26 Although coercion and repression are often predominating methods during the consolidation of power, the rulers also seek to find different means for legitimating their rule.

Hurd defines three generic reasons why an actor might obey a rule: "(1) because the actor fears the punishment of rule enforcers, (2) because the actor sees the rule as in its own selfinterest, and (3) because the actor feels the rule is legitimate and ought to be obeyed."27 In this context, depending on the characteristics of the ruler and ruled, the methods of maintaining power and preserving stability range from the material benefits that authoritarian regimes offer to the 'winning coalition', electoral/ideological legitimation of coercion and sometimes become a mix of methods.

Another means in the legitimization is the external use of force for internal political purposes (domestic policy making through foreign policy means). Skuldt, in her study, explains

\footnotetext{
${ }^{23}$ Ibid., 104.

${ }^{24}$ Paul Brooker, Non-Democratic Regimes, Second Edition (New York, NY: Palgrave Macmillan, 2009$), 139$.

${ }^{25}$ Douglass C. North, Structure and Change in Economic History, 1st ed. (New York: Norton, 1981$), 53$.

${ }^{26}$ Brooker, Non-Democratic Regimes, 2009, 144.

${ }^{27}$ Ian Hurd, "Legitimacy and Authority in International Politics," International Organization 53, no. 02 (March 1999): 379, doi:10.1162/002081899550913.
} 
this phenomenon through the logic of diversionary war theory. ${ }^{28}$ According to this logic, rulers may pursue a belligerent foreign policy in order to distract the public from internal socioeconomic and political problems, to unify the nation against an external threat, and thereby increase their own domestic political support. It is often assumed that this strategy is more likely to take place in democracies because of electoral accountability, less likely in authoritarian regimes because of the coercive basis of their authority and their insulation from society. However, because of the problem of legitimacy, greater need for the maintenance of internal unity and domestic political support makes autocratic regimes more prone to diversionary actions, which may be in different forms such as hostile diplomatic action, limited military action, and substantial military force. The construction of an external threat and pursuit of a diversionary action against that threat may serve well to increase the internal unity of the autocratic regime as well as its support in society and to legitimize it by appealing patriotic symbols of the nation. $^{29}$

The revolutionary regime, since its inception, has been in the pursuit of legitimacy to maintain its power and domestic stability. Indeed, the revolution against the Shah, which was started by the participation of a number of different groups, ended with Khomeini's hijacking. In the ethnically and politically fragmented Iranian society, Khomeini adopted a two-pronged approach to maintain domestic stability and hold his power: (1) Coercion and repression, which was executed by the IRGC (and its branches) against domestic threats. This issue was discussed in detail under the title of "Domestic and External Threats to Regime Survival." (2) Seeking legitimacy through electoral and ideological means.

The new regime was based on the convergence of two means of legitimacy; political and religious, in the words of Brooker, electoral and ideological. The regime's dual system included the velayat-e faqih system, which is the embodied form of Khomeini's ideology, and also republican institutions, which are an electoral/democratic façade that aimed for public recognition. The dominance of the Supreme Leader and the network of unelected components of the government over elected institutions have overshadowed the democratic characteristics of the regime and made it a façade. The limited political pluralism, which originates from vague candidate eligibility criteria and a multi-layered vetting process, can be given as an example of this phenomena.

Although the ideological incentives have been taken place with rational calculations of national interests, the core ideological principles -velayat-e faqih, the presumption of Islamic leadership, anti-Americanism, or anti-Zionism- have been the limits of decision-making. With the application of the expediency concept, the regime created the capability of softening the

\footnotetext{
${ }^{28}$ Skuldt, "State Sponsored Terrorism?"

${ }^{29}$ Jack S. Levy and Lily I Vakili, "Diversionary Action by Authoritarian Regimes : Argentina in the

Falklands/Malvinas Case," in The Internationalization of Communal Strife (New York, NY: Routledge, 1993), 118124.
} 
ideological strictness and legitimization of decisions that contradict ideological principles. Otherwise, the loss of these core ideological principles would make the existence of the Supreme Leader, the IRGC and unelected theoretical components of the political structure questionable.

The first decade of the revolution under Khomeini's leadership can be defined as charismatic legitimation in Weber's typology. With the death of Khomeini, the regime's ideological legitimization began to weaken. In contrast to Khomeini's powerful personality as the father of the new regime, Khamenei's lack of acceptance within the clerical community and his relatively low profile as a Supreme Leader resulted in questions to his ideological legitimacy. The increasing factionalism and, subsequently, Khatami's reformist domestic and foreign policy were perceived as threats to the regime by the conservatives gathered around the Supreme Leader. This perception was doubled with antagonistic relations with the US-Israel alliance and the increasing presence of the US in the Middle East. Additionally, arguments about the manipulation of the election results in 2009 and the regime's fierce post-election suppression of demonstrators showed how 'electoral legitimacy' is still in question.

In such domestic and foreign political environment, the IRGC was the most important actor. It could use Hezbollah and Iraqi Shiite groups against Israel and the US; it also suppressed perceived threats to the clerics' power. In other words, the IRGC became the protector of velayet-e faqih inside, a warrior against the US and Israel (executor of anti-US and anti-Zionist strategies) outside, which are the core principles of ideology.

In addition to the IRGC's strategic purposes, their extraterritorial activities also consolidate the ideological legitimacy of the regime in various ways. Their activities against the great Satan -the US- and little Satan -Israel-, which are deemed the enemies of the Muslim world, aim to appeal to the religious and nationalist feelings of society.

The successes of Hezbollah and Iraqi Shiite groups were perceived as successes for the IRGC and the regime. This has increased the regime's popularity at home. To fight for a 'higher cause' outside and being successful in this fight constitutes an effective strategy for the establishment of domestic cohesion inside and keep alive ideological motivation. This phenomenon of foreign policy produced social control can be expressed by the term 'boomerang effect.' In the logic of diversionary action, the boomerang effect can be explained as follows: The IRGC's extraterritorial activities against perceived enemies and for national interests can be defined as a kind of permanent war. This permanent war outside is a way of distracting society from domestic problems and unifying them against an external threat, which ends by increasing political support for the regime inside. Lastly, the IRGC's extraterritorial activities based on ideological motivation and national interests legitimize its existence and the regime's empowerment of it. 


\section{REFERENCES}

Brooker, Paul. Non-Democratic Regimes. Second Edition. New York, NY: Palgrave Macmillan, 2009.

- Non-Democratic Regimes: Theory, Government and Politics. New York, NY: St Martin's Press, 2000.

Bueno de Mesquita, Bruce, Alastair Smith, Randolph M. Siverson, and James D. Morrow. The Logic of Political Survival. Cambridge, MA; London: MIT Press, 2003.

Bukovansky, Mlada. Legitimacy and Power Politics: The American and French Revolutions in International Political Culture. Princeton Studies in International History and Politics. Princeton, NJ: Princeton University Press, 2002.

Campbell, David. "Truth Claims and Value-Freedom in the Treatment of Legitimacy: The Case of Weber." Journal of Law and Society 13, no. 2 (1986): 207-24. doi:10.2307/1410281.

Chehabi, H. E. "The Political Regime of the Islamic Republic of Iran in Comparative Perspective." Government and Opposition 36, no. 1 (2001): 48-70.

Hen-Tov, Elliot, and Nathan Gonzalez. "The Militarization of Post-Khomeini Iran: Praetorianism 2.0." The Washington Quarterly 34, no. 1 (February 1, 2011): 45-59. doi:10.1080/0163660X.2011.534962.

Hunter, Shireen. Iran's Foreign Policy in the Post-Soviet Era: Resisting the New International Order. Santa Barbara, Calif: Praeger, 2010.

Hurd, Ian. "Legitimacy and Authority in International Politics." International Organization 53, no. 02 (March 1999): 379-408. doi:10.1162/002081899550913.

Jack S. Levy, and Lily I Vakili. "Diversionary Action by Authoritarian Regimes : Argentina in the Falklands/Malvinas Case." In The Internationalization of Communal Strife. New York, NY: Routledge, 1993.

Keddie, Nikki. "Iran : Understanding the Enigma : A Historian' S View." Middle East Review of International Affairs 2, no. 3 (1998).

- Modern Iran: Roots and Results of Revolution. Yale University Press, 2006.

—. Qajar Iran and the Rise of Reza Khan, 1796-1925. Costa Mesa: Mazda Publishers, 1999.

Lipset, Seymour Martin. Political Man; the Social Bases of Politics. First Edition. Doubleday Anchor Books. Garden City, NY: Anchor Books, 1963.

North, Douglass C. Structure and Change in Economic History. 1st ed. New York: Norton, 1981. 
Rakel, Eva Patricia. Power, Islam, and Political Elite in Iran : A Study on the Iranian Political Elite from Khomeini to Ahmadinejad. Vol. 18. International Comparative Social Studies. Leiden ; Boston: Brill, 2009.

- Power, Islam, and Political Elite in Iran : A Study on the Iranian Political Elite from Khomeini to Ahmadinejad / by Eva Patricia Rakel. International Comparative Social Studies ; v. 18. Leiden ; Boston: Brill, 2009.

_. "The Iranian Political Elite, State and Society Relations, and Foreign Relations since the Islamic Revolution," 2008.

Skuldt, Amanda C. "State Sponsored Terrorism? Leader Survival and the Foreign Policy of Fear," 2013. https://utexas-ir.tdl.org/handle/2152/21811.

Stanley, Willis. "The Strategic Culture of the Islamic Republic of Iran." Defense Threat Reduction Agency Advanced Systems and Concepts Office, August 31, 2006. https://fas.org/irp/agency/dod/dtra/iran.pdf.

Tucker, Joshua. "Some Thoughts on Authoritarian Durability in the Middle East." The Monkey Cage, February 21, 2011. http://themonkeycage.org/2011/02/some_thoughts_on_authoritarian/.

Vatanka, Alex. "The Authoritarian Resurgence: Iran Abroad." Middle East Institute, April 30, 2015. http://www.mei.edu/content/article/authoritarian-resurgence-iran-abroad.

Walt, Stephen M. "Revolution and War." World Politics 44, no. 3 (1992): 321-68. doi:10.2307/2010542.

Walt, Stephen M. Revolution and War. Cornell Studies in Security Affairs. Ithaca, NY: Cornell University Press, 1996.

Weber, Max. Economy and Society: An Outline of Interpretive Sociology. Berkeley: University of California Press, 1978.

- From Max Weber: Essays in Sociology. Routledge Sociology Classics. Milton Park, Abingdon, Oxon ; New York: Routledge, 2009.

White, Stephen. "Economic Performance and Communist Legitimacy." World Politics 38, no. 3 (1986): 462-82. doi:10.2307/2010202. 